\title{
Novel composite materials as P-adsorption agents and their potential application as fertilizers
}

\author{
Zamparas M. ${ }^{1,}{ }^{*}$, Kapsalis V.C. ${ }^{2}$, Kanteraki A.E. ${ }^{3}$, Vardoulakis E. ${ }^{4}$, Kyriakopoulos G.L. ${ }^{5}$, Drosos M. ${ }^{6}$ and Kalavrouziotis I.K. ${ }^{7}$ \\ ${ }^{1} 6$ th Region of Healthcare: Peloponnese, Epirus, Ionian Islands and Western Greece, Ipatis 1, 26441, Patras, Greece \\ ${ }^{2}$ National Technical University of Athens, School of Mechanical Engineering, 9 Heroon Polytechniou Street, 15780 Athens, Greece \\ ${ }^{3}$ University of Patras, School of Medicine, Department of Public Health, Patras, Greece \\ ${ }^{4}$ Metals Consulting LLC, 103 Claflin Street, MA 02478, Belmont, USA \\ ${ }^{5}$ National Technical University of Athens, School of Electrical and Computer Engineering, Electric Power Division, Photometry \\ Laboratory, 9 Heroon Polytechniou Street, 15780 Athens, Greece. \\ ${ }^{6}$ Institute of Resource, Ecosystem and Environment of Agriculture (IREEA), Faculty of Biology and Environment, Nanjing Agricultural \\ University, 1 Weigang Road, 210095, Nanjing, China. \\ ${ }^{7}$ Hellenic Open University, School of Science and Technology, Parodos Aristotelous 18, 26335, Patras, Greece \\ Received: 09/05/2018, Accepted: 27/08/2018, Available online: 26/09/2018 \\ *to whom all correspondence should be addressed: e-mail: mzamparas@upatras.gr \\ https://doi.org/10.30955/gnj.002752
}

\begin{abstract}
The main objective of this study is to review the role of phosphorus in fertilizers, emphasizing in phosphate rock which is the primary source for phosphate fertilizer, with reference to harmful heavy metals as a consequence of their use. Simultaneously, this study examined the use of P-Adsorption agents as a potential application in agriculture, as the adsorbed phosphorus can be used as fertilizer or enriching soil conditioners. Therefore, it is generated a sustainable cycle taking into account a renewable resource-based Phosphorus Adsorption Agent (P-AA) leading to environmental protection and conservation of natural resources. Finally, this study highlighted new aspects that support $P$ bioavailability of Humic-metal-P (HMP) in soils, correlating with novel materials in water purification.
\end{abstract}

Abbreviations: PR: phosphate rock; P-AA: phosphorus adsorption agent; DW: dry weight; HMP: humic metal phosphate.

\section{Introduction}

Eutrophication in natural water systems has recently become a major environmental issue that threatens all kind of living organisms. Phosphate enters the aqueous environment through both natural and anthropogenic activities, such as erosion, mining, agriculture and industry. Cultural eutrophication has been considered as one of the major water pollution issues all over the world, resulting in harmful algal blooms and subsequently in depletion of dissolved oxygen as well as alteration of ecosystem community structure (Kagalou et al., 2008; Pinckney et al., 2001).

Phosphorous, due to its widespread bioavailability, is responsible for the eutrophication of water bodies, resulting in increased aquatic plant and algal growth (Dodds et al., 2009). In addition, P-control is more feasible than that of nitrogen $(N)$ because, unlike nitrogen, there is no atmospheric source of phosphorus that is bio-available. The proliferation of aquatic plants and the subsequent decomposition of organic matter usually lead to low dissolved oxygen concentrations in bottom waters and sediments, with low water renewal rates. High loadings of nutrients from anthropogenic sources resulted in hypoxic/anoxic conditions throughout the biosphere, including stratified rivers, lakes, reservoirs, estuaries and coastal waters (Smith and Schindler, 2009; Solheim et al., 2008).

In agriculture, phosphorus (P) is an essential macronutrient that can limit normal plant growth if not provided through soil at appropriate quantities of fertilizers. For soils having low concentration of $P$, this nutrient must be applied in either organic or inorganic forms to optimize crop yield performance. Organic $P$ sources, such as crop residues and animal manure, have low $\mathrm{P}$ content, and due to required massive amounts, their use is economically unfeasible (Chien et al., 2011).

In the relevant literature, there are plentiful research studies devoted to regulating ecosystems of high environmental interest via optimum $P$ stewardship. It is particularly noted that chemical lake restoration methods mainly aim at reducing the $P$ release from the sediment by improving the $P$ binding capacity and thus creating $P$ limitation of the phytoplankton. Recently, the use of several solid adsorbents was considered as a remedy for reducing the $P$ levels (Zamparas et al., 2013). Some of the materials investigated included iron oxides, red mud, fly ash and carbonates (Haghseresht et al., 2009; Huang et al., 2010; Su et al., 2011; Wanchun et al., 2011). While collectively all these materials may have 
numerous beneficial applications, each one material considered separately could have certain disadvantages. For example, the performance of iron oxide and red mud in reducing $P$ is very much affected by the solution $\mathrm{pH}$ (Tanada et al., 2003; Zeng et al., 2004). In addition, the stoichiometry of the reacting species with the phosphate anion is greater than 1:1 in most cases. The key drawback of these adsorbents is that the adsorbed phosphate can be released when some of the chemical properties of the solutions, such as $\mathrm{pH}$ and redox, change.

Nowadays, Alum, Calcite, Phoslock ${ }^{\mathrm{TM}}$ (lanthanum modified clay) and Modified Zeolite (Z2G1) are those materials commonly used to restore eutrophic water bodies with the latter two constituting the most innovative remediation materials. A recently introduced novel composite humic-acidic material, namely Bephos ${ }^{\mathrm{TM}}$, was equally effective with the above materials, bearing as little as possible negative effects for biotic and abiotic factors (Zamparas et al., 2013).

The main objective of this study is to assess the role of phosphorus in fertilizers, emphasizing in phosphate rock which is the primary source for phosphate fertilizer, with reference to harmful heavy metals as a consequence of their use. Simultaneously, this study examined the use of P-Adsorption agents as a potential application in agriculture, as the adsorbed phosphorus can be used as fertilizer or enriching soil conditioners. Finally, this study highlighted new aspects that support $P$ bioavailability of Humic-metal-P (HMP) in soils, correlating with novel materials in water purification.

\section{Biogeochemical cycle of $\mathbf{P}$}

Phosphorus (P) is the second most important macronutrient for plant growth and nutrition. It is a non-renewable resource and the demand of $P$ in the agricultural production is increasing rapidly. The bioavailability of phosphorus is precisely low due to its high fixation rates and slow diffusion in soils, making phosphorus a limiting nutrient for agricultural production (Damon et al., 2014; Gupta et al., 2014).

As a non-metallic chemical element, $\mathrm{P}$ is a key element for plant growth and a series of physiological activities that are related to energy transformations. As a mineral element, the multivalent pnictogen $\mathrm{P}$ is almost always present within inorganic phosphate rocks in its maximally oxidized state. Globally, agriculture is the primary user of phosphorus, accounting $~ 90 \%$ of the total world demand. Phosphorus is crucial for food production as all plants need an adequate amount of it (Damon et al., 2014).

Besides, phosphorus is essential for life. It is a component of DNA, RNA, ATP, and also the phospholipids that form all cell membranes. Moreover, $P$ is included in a number of cellular processes, including respiration, photosynthesis, energy storage and transfer, cell division and cell enlargement. Ample amount of phosphorus is required for seed formation, root formation, development and plant growth, and improvement of crop quality. Plants uptake $P$ from soils entering it into the food chain and disposing it to soils as decayed organic residue. Most of the phosphates are prevalent in the form of organic compounds, incorporated by living systems and upon their release to the environment, they constitute components of soil organic matter, which is then transformed by soil microorganisms in inorganic forms. $P$ exists in various forms in soils. Nevertheless, three different $P$ pools (that of solution, active and fixed) control the overall $\mathrm{P}$-cycle in nature. Plants take up phosphate from soil solutions, which include $P$ in the inorganic (mainly orthophosphate) form, and small amounts of organic P. Soil solution contains a very small fraction of the total $P$ in soil, which needs to be refilled in time, as growing plants consume the soluble source faster. However, $P$ in the form of the active phosphorus pool is the main available source for plants, released to the soil solutions. It is mostly adsorbed to small particles in the soil along with the chemical elements of $\mathrm{Ca}, \mathrm{Al}$, and inorganic $P$ pool easily mineralizes by the biogenic activities in soil. The fixed $P$ pool contains inorganic phosphate compounds that are very insoluble, as well as organic compounds that are resistant to mineralization by microorganisms in the soil. Phosphate in soils is existent for years without being bioavailable to plants, having thus very poor impact on soil fertility. The inorganic phosphate compounds in this fixed $P$ pool are more crystalline in structure, while less soluble than $P$ compounds of the active $P$ pool. However, some slow conversion between the fixed $P$ pool and the active $P$ pool does occur in soils (Delgado et al., 2002).

\section{Phosphorus fertilizers in soil}

Phosphorus does not occur in free forms, but it is incorporated in many minerals, such as phosphates. Historically-important but limited commercial sources were organic, such as bone ash and guano. Apatite, the inorganic phosphate rock, is the primary commercial source of this element. The origin of the phosphate is very important, since various heavy metals may enter into the agricultural land along with the fertilizer. Moreover, soil particles may act as sink and source of phosphate to the surrounding water, depending on various physicochemical factors.

The fixed pool of $\mathrm{P}$ also includes mostly insoluble inorganic phosphate compounds that are durable to microorganisms into the soil. Although phosphate in this pool may remain in soils for years, a slow transformation between the fixed $P$ pool and the active $P$ pool does occur (Bowsher et al., 2017).

There are some restrictions in $\mathrm{P}$ bioavailability in soils predicating plants' development (Bertin et al., 2003; Gupta et al., 2014). The bioavailability of $P$ in most of the soils is in the range of $1 \mu \mathrm{mol} / \mathrm{L}$. However, plants require $\sim 30 \mu \mathrm{mol} / \mathrm{L}$ to reaching yield maximum. The concentration within plant cells $(1-10 \mathrm{mM})$ is 10.000 -fold higher than the concentration of the natural soil solution, which means that P-uptake into plant occurs against a steep concentration gradient (Gupta et al., 2014; Sashidhar and Podile, 2010). 
In nature, $P$ is usually present as metal oxide ( $P_{\text {inorganic }}$ ) of phosphate rocks (white phosphorus and red phosphorus) or organic form (Porganic) (Hansen et al., 2004). Pinorganic composes almost $35-70 \%$ of the total $P$ in soil with apatite, strengite, and variscite being the major phosphate minerals. Nevertheless, release of available $P$ from primary minerals through weathering is too slow for plant life (Sashidhar and Podile, 2010). Secondary $P$ minerals form insoluble chemical complexes, embedding elements like aluminum ( $\mathrm{Al}$ ), calcium ( $\mathrm{Ca}$ ) and iron ( $\mathrm{Fe}$ ) (Gupta et al., 2014; Shen et al., 2011). Nonetheless, dissolution rates of $\mathrm{Al}, \mathrm{Ca}$ and Fe-salts depend on soil $\mathrm{pH}$ and particle size of minerals. Solubility of $\mathrm{Al}$ and $\mathrm{Fe}$ salts increases invariably with an increase in soil $\mathrm{pH}$ and decreases in case of $\mathrm{Ca}$ salts. Moreover, oxides and hydroxides of $\mathrm{Al} / \mathrm{Fe}$ along with the clay minerals adsorb $\mathrm{P}$ in soils, due to several adsorption sites in the clay surface (Luengo et al., 2006; Varadarajan et al., 2002).

Fertilizers are essential for plant growth providing nutrients in varying concentrations. It is estimated that $30-50 \%$ of crop yields in different parts of the world are attributed to natural or synthetic commercial fertilizers. Fertilizers normally consist of six macronutrients, viz., nitrogen $(N)$, phosphorus $(P)$, potassium $(K)$, calcium $(\mathrm{Ca})$, magnesium $(\mathrm{Mg})$, and sulfur $(\mathrm{S})$; and eight micronutrients: boron (B), chlorine ( $\mathrm{Cl})$, copper $(\mathrm{Cu})$, iron $(\mathrm{Fe})$, manganese $(\mathrm{Mn})$, molybdenum (Mo), zinc ( $\mathrm{Zn})$ and nickel (Ni).

\section{Phosphate rock as a primary source for phosphate fertilizer}

Phosphate rock (PR) is the raw material used in the manufacture of most commercial phosphate fertilizers on the market. However, properties of the PR vary extensively according to their source and physicochemical properties. Phosphorus pentoxide $\left(\mathrm{P}_{2} \mathrm{O}_{5}\right)$ is the basic constituent of the PR. Grade of PR containing $\mathrm{P}_{2} \mathrm{O}_{5}$ is around $\sim 25 \%$, with a higher content $\sim 37 \%$ to be desirable for commercial production as a phosphate fertilizer.

Sedimentary marine phosphate rock deposits are the main resources ( 75\%) of world's phosphate budget, followed by igneous and weathered deposits ( 15-20\%) and biogenic resources ( 1-2\%). Primary phosphate minerals include Fluor-apatite $\left(\mathrm{Ca}_{10}\left(\mathrm{PO}_{4}\right)_{6} \mathrm{~F}_{2}\right)$, found in igneous and metamorphic environments, hydroxy-apatite $\left(\mathrm{Ca}_{10}\left(\mathrm{PO}_{4}\right)_{6}(\mathrm{OH})_{2}\right)$, found in biogenic deposits, and carbonate-hydroxy-apatites $\left(\mathrm{Ca}_{10}\left(\mathrm{PO}_{4}, \mathrm{CO}_{3}\right)_{6}(\mathrm{OH})\right.$, found in caves, as part of bird and bat excrements (Shen et al., 2011).

However, Ores of the phosphate rock also restrain many toxic metals and radionuclides in varying concentrations that are transferred to phosphate fertilizers or tailings in production processes and eventually to soils. Depending on the source, harmful heavy metals, like cadmium (Cd), arsenic (As), chromium $(\mathrm{Cr})$, lead $(\mathrm{Pb})$, mercury $(\mathrm{Hg})$, and radionuclides, like uranium $(U)$, radium $(\mathrm{Ra})$, and thorium (Th) may be introduced into the soil along with the fertilizer, which are then absorbed by growing crop plants, causing significant health-related issues (Mortvedt et al.,
1981). However, the concentration of such contaminants varies considerably especially in the case of metals. It has been noted that application of $P$ fertilizer at a rate of $\sim 20 \mathrm{~kg} \mathrm{P} \mathrm{ha}^{-1}$ in soil heads to an impute of up to $\sim 0.01 \mathrm{~g}$ $\mathrm{ha}^{-1} \mathrm{y}^{-1}$ of $\mathrm{Hg}$ and $\sim 25 \mathrm{~g} \mathrm{ha}^{-1} \mathrm{y}^{-1}$ of $\mathrm{Cr}$ (Shen et al., 2011). Moreover, contamination of $\mathrm{Cd}$ in the environment through phosphate fertilizer is also considered a major issue in several western countries and China. It is estimated that $54-58 \%$ of the $\mathrm{Cd}$ found in the environment comes from the application of mineral phosphate fertilizers. More refined P-based fertilizers, like diammonium phosphate (DAP), and triple superphosphate (TSP), are available in the market having a higher price range.

Phosphate rock mining does oppose several concerns over environmental impacts, like landscapes transformation, extraction and pollution of a huge amount of water from adjoining water bodies and contamination with heavy metals and radioactive materials. As a normal constituent of earth's crust, rock phosphate deposits usually contain several million tons of uranium which leads to potential exposure of the environment to radiation.

There is an increasing concern over the use of $P$ fertilizers containing heavy metals, especially cadmium (Cd). Heavy metal uptake by plants is one possible entrance path into the human food chain through consumption. Numerous greenhouse and field studies have been conducted with $\mathrm{Cd}$ because it is the heavy metal of most environmental concern in terms of adverse effects from the long-term application of fertilizers. There have also been numerous studies that investigated the $\mathrm{Cd}$ impacts from the use of $P$ fertilizers (Chien et al., 2010). Particularly, Grant et al. (1998) noted that Cd concentration of P-based fertilizers, application rate, soil type, and crops growth are all important factors when considering the relationship between added $\mathrm{Cd}$ and plant uptake (Grant et al., 1998). Besides, the source of $C d$ in $P$ fertilizers is $P R$, thus, depending on the sources of PR, the $\mathrm{Cd}$-associated content with $\mathrm{P}$ in apatite minerals can vary widely (Table 1).

Table 1. Cd concentrations of $P$ and Phosphate rock (PR) from various PR sources (adapted from Chien et al., 2010)

\begin{tabular}{ccc}
\hline Source of PR & mg Cd/kg P & mg Cd/kg PR \\
\hline Australia (Duchese) & 7 & 50 \\
\hline Australia (Chrismas Island) & 43 & 275 \\
\hline Banaba (Ocean Island) & 99 & 563 \\
\hline China (Yuam) & 4 & 35 \\
\hline Egypt (Quseir) & 8 & 61 \\
\hline Israel (Arad) & 12 & 85 \\
\hline Israel (Zin) & 32 & 228 \\
\hline Jordan & 6 & 27 \\
\hline Mexico & 8 & 57 \\
\hline Morocco (Boucraa) & 38 & 240 \\
\hline Nauru & 100 & 641 \\
\hline Peru & 11 & 84 \\
\hline Rusia (Kola) & 0.2 & 1 \\
\hline South Africa & 4 & 23 \\
\hline Tunisia (Gafsa) & 38 & 108 \\
\hline USA (North Carolina) & 47 & 311 \\
\hline
\end{tabular}




\section{Materials for lake remediation}

\subsection{Alum}

Aluminum salts are very common in water treatment and have been used in water clarification and lake water restoration as flocculation agents for a long time. Alum or aluminum sulfate $\left[\mathrm{Al}_{2}\left(\mathrm{SO}_{4}\right)_{3}\right]$ is a preferable flocculant used in Europe and the United States (Cooke DG, Welch EB, Peterson SA, 1993; JEPPESEN et al., 2005). Because Al hydroxides like iron hydroxides - present in lake sediments - are natural $P$ adsorbents and because (unlike aluminum-bound phosphorus) iron-bound $P$ is soluble in reducing sediments, the $A$ l hydroxides are preferred for $P$ binding and as a long-lasting sink for bioavailable $P$. This means that aluminum acts as an active barrier system that captures and inactivates the potentially mobile $P$ from the lake bottom sediments (Jeppesen et al., 2005). Alum is at its optimal performance at $\mathrm{pH}$ values above 6 and up to 8 , effective in precipitating suspended particulates and to a lesser extent in absorbing and removing soluble forms such as phosphorus fractions. Moreover, alum is effective under anoxic conditions adsorbing the dissolved reactive phosphorus (DRP) and then the resulting floc settles on the bottom sediment (Jeppesen et al., 2005). Alum is applied to the lake water as an acidic solution. Thus, it must first be buffered, usually with sodium bicarbonate, to maintain $\mathrm{pH}$ above 6.5. If the water has low alkalinity, the result will be a pH drop below 6 and highly toxic $\mathrm{Al}^{+3}$ species will be formed; toxic $\mathrm{Al}^{+3}$ species are formed by reverse hydrolysis of the $\left[\mathrm{Al}(\mathrm{OH})_{3}\right]$ which is toxic to the lake fish. This step has to be taken in order to facilitate the flocculation process.

Additionally, in high $\mathrm{pH}$ water values, flocculation cannot be achieved; however, this requires the use of a low concentration alum solution. The wind can also disrupt the floc formation, due to the surface mixing effect (Hickey and Gibbs, 2009). As alum is added to the water column, the formation of aluminum hydroxide reduces alkalinity, so the maximum dosage of the added material is often determined as the maximum amount of $\mathrm{Al}$ than can be added until the lake water $\mathrm{pH}$ decreases to a value of 6 (Jeppesen et al., 2005). This particular application dose ensures the optimal maximum formation of the $\left[\mathrm{Al}(\mathrm{OH})_{3}\right]-\mathrm{P}$ floc with minimal occurrence of the toxic $\mathrm{Al}^{+3}$. An alternative way to calculate alum dose is based on the amount of internal phosphorus from the sediment and is calculated as five times the average summer internal phosphorus load (Cooke DG, Welch EB, Peterson SA, 2005; Zamparas and Zacharias, 2014).

Apart from the aforementioned potential alum toxicity and acidification, another non-target effect is caused by the settling of the floc, which is the smothering of the lake bed. As far as sediment toxicity is discussed, it can be caused by alum, while a critical issue is the tolerance thresholds for sediment living species between different thicknesses of alum (Gibbs et al., 2010).

Given the correct implementation of an alum application, meaning that $\mathrm{pH}$ and application rates have to be carefully considered, the material can sequester enough DRP with effectiveness and create a $P$ limitation in the water which can remediate eutrophication by eliminating toxic cyanobacterial blooms in favor of harmless phytoplanktonic species like diatoms (Downing et al., 2001). Alum can also be used for sediment capping except for its primary use as a flocculant (Cooke DG, Welch EB, Peterson SA, 1993). This material should be applied toward the end of the summer stratification when the bottom lake water is anoxic, and the accumulation of DRP is maximum. As to the duration of an implementation action, alum has an expected duration of effectiveness for 5 to 20 years, before a re-treatment to be necessary (Welch and Cooke, 1999). Nevertheless, an alum treatment may not be effective or have very limited time effectiveness, in cases where lakes are covered with macrophytes which during decomposition release high amounts of $\mathrm{P}$ into the water column (Özkundakci et al., 2011; Zamparas and Zacharias, 2014).

\subsection{Calcite (ESCaI ${ }^{T M}$ )}

Calcium carbonate $\left(\mathrm{CaCO}_{3}\right)$ is an effective natural cleaning process in hardwater lakes that act against eutrophication, trapping dissolved $\mathrm{P}$ and algae cells, as it occurs. During algal blooms, the increase of $\mathrm{pH}$ promotes the forming of $\mathrm{CaCO}_{3}$. Calcium cations and hydrogen carbonate anions, which have elevated concentration at that time, form carbon dioxide and $\mathrm{CaCO}_{3}$ which precipitate and co-precipitate $\mathrm{P}$ to the sediment in the process. Calcite or lime is a very stable $\mathrm{CaCO}_{3}$ polymorph and it is used for artificially induced $\mathrm{CaCO}_{3}$ precipitation for removing $P$ and for algae flocculation in order to improve water quality in the long term (Dittrich et al., 2011).

The co-precipitation of dissolved $\mathrm{P}$ in the form of $\mathrm{PO}_{4}^{-3}$ with calcite occurs upon the beginning of crystallization of calcite in the water. The interaction happens at the surface of the material and some surface bound $P$ can be incorporated in the calcite crystalloid structure, upon its formation. In fact the $\mathrm{P}$ and calcite co-precipitation can be linearly described. The resulting product is a complex mixture of $\mathrm{CaCO}_{3}$ and forms of calcium phosphate with the most frequently occurring final form being the mineral hydroxyl apatite $\left[\mathrm{Ca}_{5}(\mathrm{PO} 4)_{3}(\mathrm{OH})\right]$, which has a very low solubility product (Hart et al., 2003; Ross and Cloete, 2006).

Calcite has a few advantages as a phosphorus binding agent. It is an easily affordable and available non-toxic material and exists naturally in the sediments. Moreover, calcite and $\mathrm{P}$ co-precipitation is a natural process. During biogenous calcite precipitation, particulate $P$ attached to the cells ends up to the sediments because of the simultaneous phytoplankton precipitation by calcite precipitating crystals. At the same time, soluble reactive phosphorus (SRP) is stripped from the water by adsorption on the calcite surface. Moreover, adding calcite, as seed to promote $\mathrm{P}$ precipitation, lowers the interfacial energy of $\mathrm{Ca}$-phosphate interaction and the precipitation of calcite bound $\mathrm{P}$ is faster. An alternative way to induce $\mathrm{CaCO}_{3}$ precipitation is by adding calcium hydroxide $\left[\mathrm{Ca}(\mathrm{OH})_{2}\right]$ which reacts with the 
$\mathrm{CO}_{2}$ in suitably saturated lake water. $\mathrm{Ca}(\mathrm{OH})_{2}$ dissolves and facilitates the formation of $\mathrm{CaCO}_{3}$ mainly by increasing $\mathrm{pH}$. However, this has the obvious drawback of creating very high alkalinity water which is toxic for the majority of aquatic organisms (Dittrich et al., 2011; Mehner et al., 2008).

\subsection{Modified zeolite (Z2G1)}

A modified zeolite named Z2G1 has been developed by Scion, Rotorua, New Zealand and manufactured by Blue Pacific Minerals Ltd as phosphate adsorption agent. Natural zeolite is a porous aluminosilicate material that has a large specific absorptive surface area due to a fine porous structure and is also a good cation absorbent (e.g. $\mathrm{NH}^{+}$). Z2G1 was modified with an Al salt for improved $\mathrm{P}$ uptake capacity, being able to remove both $P$ and N. Z2G1 does not release $\mathrm{Al}$ into the water column. The increased concentration of potentially bioavailable $\mathrm{Al}$ in the material could have environmental effects, although, based on a laboratory assay, its toxicity is minimal (Vopel et al., 2008).

A continuous flow incubation system was applied to assess Z2G1 in terms of efficacy and sustainability regarding flux measurements in simulated stratified (anoxic) and mixed (aerobic) conditions. Comparing the Z2G1 modified zeolite with alum, a few advantages over it appeared. First, Z2G1 did not require $\mathrm{pH}$ buffering of the lake water and it has the high $P$ binding capacity of alum (Vopel et al., 2008). Also unlike alum, modified zeolite did not acidify lake water following the application, minimizing the potential for aluminum toxicity, which is markedly higher at low $\mathrm{pH}$ (Gibbs and Özkundakci, 2010; Zamparas and Zacharias, 2014).

In the relevant literature, the Z2G1 modified zeolite was used in an application in Lake Okaro in September 2007. Lake Okaro is a small eutrophic lake (surface area $0.32 \mathrm{~km}^{2}$ ) and it suffers frequent cyanobacterial blooms caused by high nitrogen and phosphorus inputs from the catchment and significant internal $P$ loading released from the sediments during summer stratification. The results showed that modified zeolite $Z 2 \mathrm{G} 1$ was able to completely remove $\mathrm{P}$ from the water column of Lake Okaro (Gibbs and Wilson, 2007). The higher dose rate of the 1-3 $\mathrm{mm}$ grain size material was more effective in removing $P$ than the lower dose rate in natural anoxic lake water. Moreover, from the use of varying grain size it was shown that the $<1 \mathrm{~mm}$ grain size absorbed about $45 \%$ more $P$ than the $1-3 \mathrm{~mm}$ grain size in both the natural and phosphate-enriched water incubation trials for the same period. This is because of the greater active surface area that a finer material has over a coarser one.

Regarding the metal fluxes in the sampled cores between the sediment and the water, these were generally low, and even when the incubation tubes were made anoxic, the metal concentrations were generally much lower than those just above the sediment measured at the time of the core sampling. This could be because of the bottom stir up during the core sampling (Gibbs and Wilson, 2007). Additionally, a shift of the reductionoxidation (redox) boundary can cause the release of metals with sensitivity and mobility under anaerobic conditions (Himmelheber et al., 2008). Although the small layer thickness of the $22 \mathrm{G} 1$ had the potential to enhance metal mobilization from the sediments, there was very low or no metal fluxes from the sediments in aerobic or anaerobic conditions. The very few changes in metal concentrations in the water above the sediment, particularly under anoxic conditions, caused because of the zeolite substrate of the Z2G1, is a good-cation absorber.

In parallel, it was noted that Z2G1 can inhibit nitrification and denitrification under aerobic conditions. This means that $\mathrm{Z2G1}$ could increase $\mathrm{N}$ retention in the lake if it was applied in the permanently aerobic zones, for instance, the littoral zone of Lake Okaro. In this lake, the permanently aerobic littoral zone above $5 \mathrm{~m}$ is the only habitable area of the lake bed for most of the year. Hence, for this life-supporting zone to be protected Z2G1 should be applied only below that depth and fortunately, this can be done accurately because of its granular composition and its advantageous settling speed.

From this study, it is established that the Z2G1 modified zeolite is an adequate sediment capping material for sediment phosphorus release blocking in anoxic conditions, at the tested dose rates on the sediment cores. Furthermore, the material absorbed cationic metals which mean that the cation retaining abilities of the zeolite were still in effect and there was an absorption of $\mathrm{NH}_{4}{ }^{+}$from the overlying water and the stopping of $\mathrm{NH}_{4}-\mathrm{N}$ release from the sediment. Consequently, we infer that the $\mathrm{Z2G1}$ is the only known sediment capping agent that inactivates both $\mathrm{P}$ and $\mathrm{N}$. Nonetheless, while from the reported results of the core incubation study it can be noted that the material is potent in blocking the $\mathrm{N}$ and $P$ release from the lake sediments, it remains uncertain to draw general conclusions from these to an actual whole lake trial (Gibbs and Wilson, 2007; Özkundakci et al., 2011). Conclusively, the Z2G1 needs to be tested in that way to give more precise conclusions about its usability as a lake restoration method as well as for its long-term effects after several or many years of usage in lake restoration.

\subsection{Phoslock PM $^{T M}$}

Phosphate precipitation by lanthanum (a rare earth element) was more effective in a wide $\mathrm{pH}$ range $(4.5-8.5)$ than either Fe or Al salts. Moreover, the molar ratio of La to phosphate anion is $1: 1$, as resulting from the chemical reaction of: $\mathrm{La}^{3+}+\mathrm{PO}_{4}{ }^{-3} \rightarrow \mathrm{LaPO}_{4}$. The solubility product $\left(\mathrm{K}_{\mathrm{sp}}\right)$ of the La-phosphate complex is particularly low (24.76 and 27.92) in both aqueous and seawater solutions, making it the least soluble of the rare earth-phosphate complexes. The complex is known to be so insoluble in low La and phosphate concentrations and low pH conditions (Diatloff et al., 1993). 
The research into the use of lanthanum for reducing phosphates has revealed that, depending on the concentration and the rate of application, this component can be toxic to aquatic life. This problem can be overcome by embedding La into the structure of clay minerals, such as bentonite by taking advantage of their cation exchange capacity (CEC). During the manufacturing of Phoslock ${ }^{\mathrm{TM}}$, lanthanum ions are exchanged with the bentonite internal surface random adsorbed exchangeable cations. This mechanism enabled the development of a La-modified bentonite by CSIRO (Commonwealth Scientific and Industrial Research Organization) during the 90s (Robb et al., 2003). Phoslock ${ }^{\mathrm{TM}}$ forms a highly stable mineral known as rhabdophane $\left(\mathrm{LaPO}_{4}\right)$ in the presence of $P$ species such as orthophosphates that are common oxyanions. The rare earth element in the clay structure can either react with the phosphate anion in the water body or remain in that structure under a vast range of environmental conditions (Zamparas et al., 2015b). Although La ions could be toxic to some aquatic organisms, particularly cladocerans such as Daphnia (Barry and Meehan, 2000), hence the potential liberation of La ions from the bentonite implies a significant environmental risk (Akhurst et al., 2004), Phoslock ${ }^{\text {TM }}$ has been classified as not hazardous (Martin and Hickey, 2001). A leachate experiment showed La could be released from the material, but in only insignificant quantities of $0.13-2.13 \mu \mathrm{g} / \mathrm{L}$. In this scenario, provided Phoslock $^{\mathrm{TM}}$ can be applied in a worst-case dose of 250 mg/L (Lürling and Tolman, 2010).

Table 2. Comparison of phosphate adsorption capacity $\left(q_{m}\right)$ of tested material with some literature values (adapted from Zamparas et al., 2013)

\begin{tabular}{ccc}
\hline Material & $\mathbf{q}_{\mathbf{m}}$ Phosphate $\mathbf{( m g / g )}$ & $\mathbf{p H}$ range* \\
\hline Alum & $12-13.8$ & $5.5-8.2$ \\
\hline Ferric hydroxide & 16.9 & $5.5-8.2$ \\
\hline Phoslock $^{\mathrm{TM}}$ & 10.5 & $5-7$ \\
\hline Al-bentonite & 12.7 & $3-5$ \\
\hline Fe-bentonite & 11.2 & $5-7$ \\
\hline $\begin{array}{c}\text { Iron oxide } \\
\text { tailing }\end{array}$ & 8.6 & 3.2 \\
\hline Goethite & 6.4 & \\
\hline Red mud & 0.8 & $5-6$ \\
\hline Modified fly ash & 9.1 & 2 \\
\hline BephosTM & 26.5 & $5-10$ \\
\hline
\end{tabular}

* pH range under which the maximum efficiency was measured.

According to Liu et al. (Liu et al., 2009) the effectiveness of Phoslock $^{\mathrm{TM}}$ was tested and evaluated both in laboratory and field trials. The results of static and dynamic simulation experiments under different environmental conditions showed that with the $0.5 \mathrm{~kg} / \mathrm{m}^{2}$ application rate of Phoslock ${ }^{\mathrm{TM}}$ the orthophosphate $\left(\mathrm{PO}_{4}-\mathrm{P}\right)$ concentration of the overlying water decreased to a low level $(\leq 0.02 \mathrm{mg} / \mathrm{L})$ within 10 days. Even under anaerobic and high $\mathrm{pH}(\mathrm{pH}=9.0)$ conditions, the phosphate release suppression efficiency reached $98.3 \%$, and the P-release rate was $-8.20 \mathrm{mg} / \mathrm{m}^{2} \mathrm{~d}$, where negative values indicate $P$ adsorption by Phoslock ${ }^{\mathrm{TM}}$.

\subsection{Bephos $^{T M}$}

Bephos $^{\mathrm{TM}}$ (nomination is originated from the words "Bentonite" and "phosphorus") is a novel low-cost composite material embedding $\mathrm{Fe}, \mathrm{Cu}$ ions and humic acid in the interlayer space of a natural bentonite. This material is derived from a novel precursor material Zenith/Fe (Zamparas et al., 2012) that it is absent upon the addition of humic acids. Its properties have been studied in detail elsewhere (Miltiadis Zamparas et al., 2013). The point of zero charge (PZC) of the material is $\mathrm{pH}$ 8.8. This means that the positive charges of bound $\mathrm{Fe}^{3+}$, $\mathrm{Cu}^{2+}$, and the clay surface groups counterbalance the negative charges of the HA. From the functional point of view, the existence of both positively-charged sites, e.g. $\mathrm{Fe}^{3+}, \mathrm{Cu}^{2+}$, surface $(+)$ groups as well as negatively charged sites (e.g. due to $\mathrm{HA}$ ) render Bephos ${ }^{\mathrm{TM}}$ the capability to bind both anionic species e.g. $\mathrm{PO}_{4}$, as well cationic species, e.g. $\mathrm{NH}^{+}$. In addition, the important information from XRD data (Zamparas et al., 2013) is that $\mathrm{Fe}$ and $\mathrm{Cu}$ ions have been incorporated in solid crystalline phases, while other phases have been depleted from the pristine clay. Humic acid is rich in carboxylates which act as strong anchoring sites for $\mathrm{Fe}$ and $\mathrm{Cu}$ ions. Thus, the formed COO-Fe, COO-Cu sites behave as coordination sites for $\mathrm{P}$ and $\mathrm{N}$ due to the known strong affinity of $\mathrm{Fe}$ and $\mathrm{Cu}$ to coordinate $\mathrm{P}$ and $\mathrm{N}$ atoms. Bephos ${ }^{\mathrm{TM}}$ is a novel composite material where $\mathrm{Fe}, \mathrm{Cu}, \mathrm{HA}$ and clay lamellas are strongly interconnected (Zamparas et al., 2015a).

Moreover, the modified clay was highly efficient for simultaneous phosphorus removal from water at the wide range of $\mathrm{pH}$ value 5 to 9 . Its efficiency is maintained at alkaline $\mathrm{pH}(\mathrm{pH}$ 8-9) in contrast with most materials, whose ability in adsorbing phosphorus drops dramatically under these conditions. This is of particular importance as in eutrophic waters the $\mathrm{pH}$ value ranges between 8 and 9 . In addition, the adsorption capacity for phosphate and ammonium followed the order: Fresh water > brackish > marine water (Zamparas et al., 2013).

\section{The role of humics in agriculture}

Humic acids are complex organic molecules that are formed by the breakdown of organic matter. They influence soil fertility through their water-holding capacity effect on soil, making important contributions to soil stability and fertility, leading to exceptional plant growth and nutrient uptake. Plant growth is also improved by the ability of the plant to uptake and receive more nutrients. Humic acid is especially beneficial in freeing up nutrients in the soil to become available to the plants. Organic acids such as citric, malic, and oxalic-being released as exudates-can form complexes with the $\mathrm{Fe}$ or $\mathrm{Al}$ phosphates, and thereby enhance the uptake of plant available phosphates. It is predicted that these chelators are more effective in $\mathrm{P}$ mobilization comparing to other elements. Even, $\mathrm{P}$ adsorption sites on the soil particle may be blocked by forming complexes with cations on soil mineral surfaces (Urrutia et al., 2014). For instance when an aluminum and a phosphorous are bounded together, humic acid detaches them, making the phosphorus 
available for the plant (Figure 1). Humic acid is also especially important because of its ability to chelate micronutrients increasing their bio-availability (Delgado et al., 2002).

In the relevant literature there are also numerous studies that co-evaluated several humic and fulvic substances, metals and $P$, that reported the formation of HMP in solution, as well as their presence in lakes, freshwaters, and soil solutions (Delgado et al., 2002; Leytem and Westermann, 2003; Urrutia et al., 2014).

Regarding the availability of HMP-complexed $\mathrm{P}$ for plant uptake, a number of tests showed that diverse plant species can acquire $P$ from HMP, at least at the same level as that can be uptaken from conventional $\mathrm{P}$ sources (monopotassium phosphate, $\mathrm{KH}_{2} \mathrm{PO}_{4}$ ) (Urrutia et al., 2014). Although plants receiving HMP are developing similar or higher dry matter than control plants fed with $\mathrm{KH}_{2} \mathrm{PO}_{4}$, the concentration of $\mathrm{P}$ in the leaf of HMP-treated plants is significantly lower than that of control plants fed with $\mathrm{KH}_{2} \mathrm{PO}_{4}$. This fact indicates that the physiological utilization efficiency of plants for $\mathrm{HM}-\mathrm{P}$ was higher than for $\mathrm{KH}_{2} \mathrm{PO}_{4}-\mathrm{P}$.
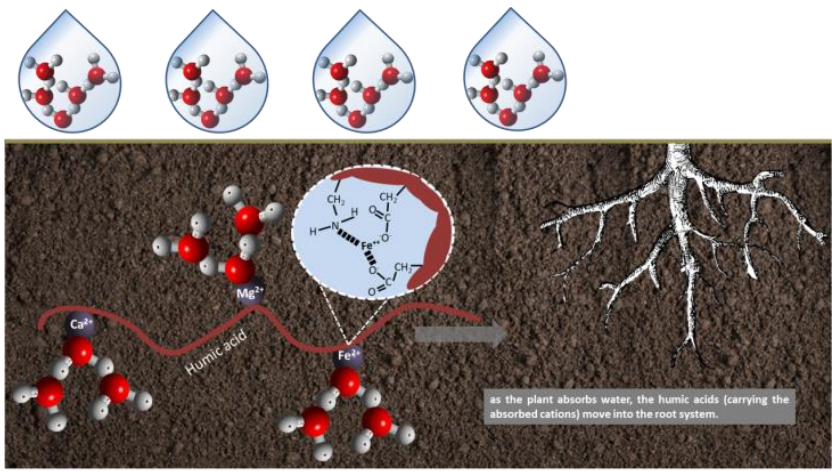

Figure 1. Humic acid transport nutrients close to the plant roots

This case is also based on the fact that the nutrient-uptake efficiency, which is the ratio between the nutrient taken up by the plant and the nutrient available in the rhizosphere, is higher in those plants receiving $\mathrm{KH}_{2} \mathrm{PO}_{4}-\mathrm{P}$. $P$-included in HMP is not in a free form but in complexed form. Therefore, plant roots have to compete with HMP to uptake HMP-complexed P. It also might involve the activation of stress responses under conditions of $\mathrm{P}$ deficiency, with the exertion of additional energy. In order to reduce this energy-intensive demand, plants can activate specific mechanisms to optimize the physiological and metabolic utilization of P-presented in the shoot (Urrutia et al., 2014).

This explains why plants receiving $P$ from HM-P have the same shoot DW as those fed with $\mathrm{P}$ from $\mathrm{KH}_{2} \mathrm{PO}_{4}$ but having a lower $\mathrm{P}$ concentration in the leaf. Therefore, $\mathrm{P}$ utilization efficiency is higher in plants fed with HMP complexes, while P-uptake efficiency is higher for plants fed with monopotassium phosphate $\left(\mathrm{KH}_{2} \mathrm{PO}_{4}\right)$. The aforementioned results suggest that fertilizers containing HMP support higher $P$ efficiency of plants than those based on water-soluble $P$.

\section{Potential usefulness of lake restoration materials in agriculture}

In the previous sections, $\mathrm{P}$-adsorption materials have been studied only for lake restoration. However, there is the possibility to recycle these materials for agricultural use. Most of these materials are clay-based, so their addition to soil may not disturb the ecosystem but improve its cation exchange capacity (CEC). Materials like Bephos ${ }^{\mathrm{TM}}$ contain also monovalent iron and copper that could act like micro-nutrients. However, their most advantageous feature is their ability to retardedly adsorb phosphorous and, then, to slowly release it. Specifically, it has been reported that Bephos ${ }^{\mathrm{TM}}$ can uptake $26.5 \mathrm{~g} \mathrm{~kg}^{-1}$ phosphate, gradually releasing $5.3 \mathrm{~g} \mathrm{~kg}^{-1}$ every 6 months (Zamparas et al., 2013). Considering the need of phosphorous in crop fields that is $\sim 50 \mathrm{~kg} \mathrm{ha}^{-1}$ per year (for the crops of wheat, maize, and tomato), the need of 5 tn ha ${ }^{-1}$ of Bephos ${ }^{T M}$ is estimated, that would retardedly release the necessary phosphorus over a period of more than 3 years. Bephos ${ }^{\mathrm{TM}}$ is not just a modified clay, but it can be considered as a modified organo-mineral clay since it contains humic acid (Zamparas et al., 2013). The application of 5 th haBephos $^{\mathrm{TM}}$ in the field would result in the addition of $6 \mathrm{~kg} \mathrm{ha}^{-1}$ humic acid. However, the aforementioned results are obtained for Bephos ${ }^{\mathrm{TM}}$, because there is lack of information about other P-adsorption derivatives. Moreover, the P-release ratio can be measured in water, not in soil. It is also noteworthy noting the need for lowering the cost of these materials since these are proven effectively recyclable in agriculture after being used in lake restoration. However, further research is needed to estimate the actual release of bound phosphorous of these materials in soil and their interaction mechanisms with mycorrhizal (Cozzolino et al., 2013).

\section{Conclusions}

Humic-metal-phosphate complexes can decrease phosphate fixation in soils and increase plant growth and phosphate uptake. Phosphorus fertilizers, containing humic-metal-phosphate complexes, are proven effective to improve plant growth and $\mathrm{P}$ uptake with respect to conventional fertilizers, such as single superphosphate. The values of parameters related to plant phosphorusutilization efficiency (PUt E) suggest that the regulation of root acquisition of phosphate from these complexes could introduce a controlling system for the optimization of metabolic $P$ utilization in the shoot, and another controlling system that involves stress responses of roots under phosphorus deficiency.

The properly designed application of chemical restoration methods can reduce the concentration of nutrients and improve the water quality in eutrophic ecosystems. However, the demand for fertilizer is increasing worldwide, contrarily to the global phosphate supply shortage (Cozzolino et al., 2013). It seemed that the application of phosphate fertilizers has reached its limits and it is necessary to be transformed in a sustainable way. Moreover, phosphate fertilizers losses not only reduce 
nutrients efficiency, resulting in low plant yields, but also create adverse impacts on the environment (Chen et al., 2018). Thus, the use of P-adsorption agents (Behrens and Appel, 2016; Ramasahayam et al., 2012) can prove alternative methods in which the adsorbed phosphorus can be used as fertilizer or enriching soil conditioners. Therefore, it is generated a sustainable cycle taking into account a renewable resource-based Phosphorus Adsorption Agent (P-AA) leading to environmental protection and conservation of natural resources. P-AA for removal and recovery of phosphorus from eutrophic water bodies are a promising technique but require further study in its feasible scaling up to the agricultural sector worldwide.

\section{References}

Akhurst D., Jones G.B. and McConchie D.M. (2004), The application of sediment capping agents on phosphorus speciation and mobility in a sub-tropical dunal lake, Marine and Freshwater Research, 55, 715. https://doi.org/10.1071/ MF03181.

Barry M.J. and Meehan B.J. (2000), The acute and chronic toxicity of lanthanum to Daphnia carinata, Chemosphere, 41, 1669-1674.

Behrens S. and Appel I. (2016), Magnetic nanocomposites, Current Opinion in Biotechnology, 39, 89-96. https://doi.org/10.1016/j.copbio.2016.02.005.

Bertin C., Yang X. and Weston L.A. (2003), The role of root exudates and allelochemicals in the rhizosphere, Plant \& Soil, https://doi.org/10.1023/A:1026290508166.

Bowsher A.W., Evans S., Tiemann L.K. and Friesen M.L. (2017), Effects of soil nitrogen availability on rhizodeposition in plants: a review, Plant Soil, 1-27. https://doi.org/ 10.1007/s11104-017-3497-1.

Chen J., Lü S., Zhang Z., Zhao X., Li X., Ning P. and Liu M. (2018), Environmentally friendly fertilizers: A review of materials used and their effects on the environment. The Science of the Total Environment, https://doi.org/10.1016/ j.scitotenv.2017.09.186.

Chien S.H., Prochnow L.I., Tu S., Snyder C.S. (2010), Agronomic and environmental aspects of phosphate fertilizers varying in source and solubility: an update review, Nutrient Cycling in Agroecosystems, 89, 229-255. https://doi.org/10.1007/ s10705-010-9390-4.

Cooke D.G., Welch E.B., Peterson S. and Nichols S.A. (2005), Restoration and Management of Lakes and Reservoirs, 3rd ed., CRC Press.

Cooke D.G., Welch E.B., Peterson S., Nichols S.A. (1993), Proceedings of the Third International Workshop on Phosphorus in Sediments, Springer Netherlands, Dordrecht. https://doi.org/10.1007/978-94-011-1598-8.

Cozzolino V., Di Meo V. and Piccolo A. (2013), Impact of arbuscular mycorrhizal fungi applications on maize production and soil phosphorus availability, Journal of Geochemical Exploration, 129, 40-44. https://doi.org/ 10.1016/j.gexplo.2013.02.006.

Damon P.M., Bowden B., Rose T. and Rengel Z. (2014), Crop residue contributions to phosphorus pools in agricultural soils: A review, Soil Biology \& Biochemistry, https://doi.org/10.1016/j.soilbio.2014.03.003.
Delgado A., Madrid A., Kassem S. and Andreu L. (2002). Phosphorus fertilizer recovery from calcareous soils amended with humic and fulvic acids, 277-286.

Diatloff E., Asher C.J., Smith F.W. (1993), Use of GEOCHEM-PC to predict rare earth element (REE) species in nutrient solutions, Plant Soil, 155-156, 251-254. https://doi.org/ 10.1007/BF00025031.

Dittrich M., Gabriel O., Rutzen C. and Koschel R. (2011), Lake restoration by hypolimnetic $\mathrm{Ca}(\mathrm{OH}) 2$ treatment: impact on phosphorus sedimentation and release from sediment, The Science of the Total Environment, 409, 1504-1515. https://doi.org/10.1016/j.scitotenv.2011.01.006.

Dodds W.K., Bouska W.W., Eitzmann J.L., Pilger T.J., Pitts K.L., Riley A.J., Schloesser J.T. and Thornbrugh D.J. (2009), Policy analysis: Eutrophication of U.S. freshwaters: Damages, Environmental Science \& Technology, 43(8). https://doi.org/ 10.1021/es801217q.

Downing J.A., Watson S.B. and McCauley E. (2001), Predicting Cyanobacteria dominance in lakes, Canadian Journal of Fisheries and Aquatic Sciences, 58, 1905-1908. https://doi.org/10.1139/f01-143.

Gibbs M. and Özkundakci D. (2010), Effects of a modified zeolite on $\mathrm{P}$ and $\mathrm{N}$ processes and fluxes across the lake sedimentwater interface using core incubations, Hydrobiologia, 661, 21-35. https://doi.org/10.1007/s10750-009-0071-8.

Gibbs M. and Wilson P. (2007), P-inactivation efficacy of Z2G1 as a capping agent on Lake Okaro sediment P-inactivation efficacy of Z2G1 as a capping agent on Lake Okaro sediment.

Gibbs M.M., Hickey C.W. and Özkundakci D. (2010), Sustainability assessment and comparison of efficacy of four P-inactivation agents for managing internal phosphorus loads in lakes: sediment incubations, Hydrobiologia, 658, 253-275. https://doi.org/10.1007/s10750-010-0477-3.

Grant C.A., Buckley W.T., Bailey L.D. and Selles F. (1998), Cadmium accumulation in crops, Canadian Journal of Plant Science, 78, 1-17. https://doi.org/10.4141/P96-100.

Gupta D.K., Chatterjee S., Datta S., Veer V. and Walther C. (2014), Role of phosphate fertilizers in heavy metal uptake and detoxification of toxic metals, Chemosphere, https://doi.org/10.1016/j.chemosphere.2014.01.030.

Haghseresht F., Wang S., Do D.D. (2009), A novel lanthanummodified bentonite, Phoslock, for phosphate removal from wastewaters, Applied Clay Science, 46, 369-375. https://doi.org/10.1016/j.clay.2009.09.009.

Hansen J.C., Cade-Menun B.J. and Strawn D.G. (2004), Phosphorus speciation in manure-amended alkaline soils, Journal of Environmental Quality, 33, 1521-1527. https://doi.org/10.2134/jeq2004.1521.

Hart B., Roberts S., James R., Taylor J., Donnert D. and Furrer R. (2003), Use of active barriers to reduce eutrophication problems in urban lakes, Water Science and Technology, 157-163.

Hickey C.W. and Gibbs M.M. (2009), Lake sediment phosphorus release management - Decision support and risk assessment framework, New Zealand Journal of Marine and Freshwater Research, 43, 819-856. https://doi.org/ 10.1080/00288330909510043.

Himmelheber D.W., Taillefert M., Pennell K.D. and Hughes J.B. (2008), Spatial and temporal evolution of biogeochemical processes following in situ capping of contaminated 
sediments, Environmental Science \& Technology, 42, 41134120. https://doi.org/10.1021/es702626x.

Huang H., Xiao X., Yan B. and Yang L. (2010), Ammonium removal from aqueous solutions by using natural Chinese (Chende) zeolite as adsorbent, Journal of Hazardous Materials, 175, 247-252. https://doi.org/10.1016/j.jhazmat. 2009.09.156.

Jeppesen E., Sondergaard M., Jensen J.P., Havens K.E., Anneville O., Carvalho L., Coveney M.F., Deneke R., Dokulil M.T., Foy B., Gerdeaux D., Hampton S.E., Hilt S., Kangur K., Kohler J., Lammens E.H.H.R., Lauridsen T.L., Manca M., Miracle M.R., Moss B., Noges P., Persson G., Phillips G., Portielje R., Romo S., Schelske C.L., Straile D., Tatrai I., Willen E. and Winder M. (2005), Lake responses to reduced nutrient loading - an analysis of contemporary long-term data from 35 case studies, Freshwater Biology, 50, 1747-1771. Https://doi.org/10.1111/j.1365-2427.2005.01415.x.

Kagalou I., Papastergiadou E. and Leonardos I. (2008), Long term changes in the eutrophication process in a shallow Mediterranean lake ecosystem of W. Greece: Response after the reduction of external load, Journal of Environmental Management, 87, 497-506. https://doi.org/10.1016/ j.jenvman.2007.01.039.

Leytem A.B. and Westermann D.T. (2003), Phosphate sorption by pacific northwest calcareous soils, Soil science, 168, 368375. https://doi.org/10.1097/01.ss.0000070911.55992.0e.

Liu Y., Tian K. and Winks A. (2009), Water eutrophication prevention by phoslock flocculation and sediment capping reaction, Proceedings - 2009 International Conference on Environmental Science and Information Application Technology, ESIAT 2009, IEEE, pp. 349-352. https://doi.org/ 10.1109/ESIAT.2009.316.

Luengo C., Brigante M., Antelo J. and Avena M. (2006), Kinetics of phosphate adsorption on goethite: comparing batch adsorption and ATR-IR measurements, Journal of Colloid and Interface Science, 300, 511-518. https://doi.org/10.1016/ j.jcis.2006.04.015.

Lürling M. and Tolman Y. (2010), Effects of lanthanum and lanthanum-modified clay on growth, survival and reproduction of Daphnia magna, Water Research, 44, 309319. https://doi.org/10.1016/j.watres.2009.09.034.

Martin M.L. and Hickey C.W. (2001), Determination of HSNO ecotoxic thresholds for granular PhoslockTM, phase 1: Acute toxicity.

Mehner T., Diekmann M., Gonsiorczyk T., Kasprzak P., Koschel R., Krienitz L., Rumpf M., Schulz M. and Wauer G. (2008), Rapid recovery from eutrophication of a stratified lake by disruption of internal nutrient load, Ecosystems, 11, 11421156. https://doi.org/10.1007/s10021-008-9185-5.

Mortvedt J.J., Mays D.A. and Osborn G. (1981), Uptake by wheat of cadmium and other heavy metal contaminants in phosphate fertilizers1, Journal of Environmental Quality, 10, 193. https://doi.org/10.2134/jeq1981.004724250010000200 $14 \mathrm{x}$.

Özkundakci D., Duggan I.C. and Hamilton D.P. (2011), Does sediment capping have post-application effects on zooplankton and phytoplankton?, Hydrobiologia, 661, 55-64. https://doi.org/10.1007/s10750-009-9938-y.

Pinckney J.L., Paerl H.W., Tester P. and Richardson T.L. (2001), The role of nutrient loading and eutrophication in estuarine ecology, Environmental Health Perspectives, 109(Suppl), 699706. https://doi.org/10.1289/ehp.01109s5699.

Ramasahayam S.K., Gunawan G., Finlay C. and Viswanathan T. (2012), Renewable resource-based magnetic nanocomposites for removal and recovery of phosphorous from contaminated waters. Water Air and Soil Pollution, 223, 4853-4863. https://doi.org/10.1007/s11270-012-1241-2.

Robb M., Greenop B., Goss Z., Douglas G. and Adeney J. (2003), Application of Phoslock TM, an innovative phosphorus binding clay, to two Western Australian waterways: preliminary findings, Hydrobiologia, 494, 237-243. https://doi.org/10.1023/A:1025478618611

Ross G. and Cloete P.T.E. (2006), Phoslock ${ }^{\circledR}$ field trial at K ' shani lake lodge, hartbeespoort dam January-December 2006 summary of results, 1-15.

Sashidhar B. and Podile A.R. (2010), Mineral phosphate solubilization by rhizosphere bacteria and scope for manipulation of the direct oxidation pathway involving glucose dehydrogenase, Journal of Applied Microbiology, 109, 1-12. https://doi.org/10.1111/j.1365-672.2009.04654.x.

Shen J., Yuan L., Zhang J., Li H., Bai Z., Chen X., Zhang W. and Zhang F. (2011), Phosphorus dynamics: from soil to plant, Plant physiology, 156, 997-1005. https://doi.org/10.1104/ pp.111.175232.

Smith V.H. and Schindler D.W. (2009), Eutrophication science: where do we go from here?, Trends in Ecology \& Evolution, 24, 201-207. https://doi.org/10.1016/J.TREE.2008.11.009.

Solheim A.L., Rekolainen S., Moe S.J., Carvalho L., Phillips G., Ptacnik R., Penning W.E., Toth L.G., O'Toole C., Schartau A.K.L. and Hesthagen T. (2008), Ecological threshold responses in European Lakes and their applicability for the Water Framework Directive (WFD) implementation: synthesis of lakes results from the REBECCA project. https://doi.org/10.1007/s10452-008-9188-5.

Su J., Huang H.-G., Jin X.-Y., Lu X.-Q. and Chen Z.-L. (2011), Synthesis, characterization and kinetic of a surfactantmodified bentonite used to remove $\mathrm{As}(\mathrm{III})$ and $\mathrm{As}(\mathrm{V})$ from aqueous solution, Journal of Hazardous Materials, 185, 6370. https://doi.org/10.1016/j.jhazmat.2010.08.122.

Tanada S., Kabayama M., Kawasaki N., Sakiyama T., Nakamura T., Araki M. and Tamura T. (2003), Removal of phosphate by aluminum oxide hydroxide, Journal of Colloid and Interface Science, 257, 135-140. https://doi.org/10.1016/S00219797(02)00008-5.

Urrutia O., Erro J., Guardado I., San Francisco S., Mandado M., Baigorri R., Claude Yvin J. and Ma Garcia-Mina J. (2014), Physico-chemical characterization of humic-metal-phosphate complexes and their potential application to the manufacture of new types of phosphate-based fertilizers, Journal of Plant Nutrition and Soil Science, 177, 128-136. https://doi.org/10.1002/jpln.201200651.

Varadarajan D.K., Karthikeyan A.S., Matilda P.D. and Raghothama K.G. (2002), Phosphite, an analog of phosphate, suppresses the coordinated expression of genes under phosphate starvation, 1. https://doi.org/10.1104/ pp.010835.1232.

Vopel K., Gibbs M., Hickey C.W. and Quinn J. (2008), Modification of sediment-water solute exchange by sediment-capping materials: effects on $\mathrm{O} 2$ and $\mathrm{pH}$, Mar. Freshw. Res., 59, 1101. https://doi.org/10.1071/MF08130. 
Wanchun T., Qiuyun W., Yunbo W. and Zhengke P. (2011), Adsorption of nitrogen and phosphorus on natural zeolite and its influencing factors, 2011 Third International Conference on Measuring Technology and Mechatronics Automation, 347-350. https://doi.org/10.1109/ ICMTMA.2011.88.

Welch E.B. and Cooke G.D. (1999), Effectiveness and longevity of phosphorus inactivation with alum, Lake and Reservoir Management, 15, 5-27. https://doi.org/10.1080/ 07438149909353948.

Zamparas M., Deligiannakis Y. and Zacharias I. (2013), Phosphate adsorption from natural waters and evaluation of sediment capping using modified clays, Desalination and Water Treatment, 51, 2895-2902. https://doi.org/10.1080/ 19443994.2012.748139.

Zamparas M., Drosos M., Deligiannakis Y. and Zacharias I. (2015a), Eutrophication control using a novel bentonite humic-acid composite material Bephos ${ }^{\mathrm{TM}}$, Journal of Environmental Chemical Engineering, 3, 3030-3036. https://doi.org/10.1016/j.jece.2014.12.013.

Zamparas M., Drosos M., Georgiou Y., Deligiannakis Y. and Zacharias I. (2013), A novel bentonite-humic acid composite material Bephos ${ }^{\mathrm{TM}}$ for removal of phosphate and ammonium from eutrophic waters, Chemical Engineering Journal, 225, 43-51. https://doi.org/10.1016/j.cej.2013.03.064.

Zamparas M., Gavriil G., Coutelieris F.A. and Zacharias I. (2015b), A theoretical and experimental study on the P-adsorption capacity of Phoslock ${ }^{\mathrm{TM}}$, Applied Surface Science, 335, 147152. https://doi.org/10.1016/j.apsusc.2015.02.042.

Zamparas M., Gianni A., Stathi P., Deligiannakis Y. and Zacharias I. (2012), Removal of phosphate from natural waters using innovative modified bentonites, Applied Clay Science, 62-63, 101-106. https://doi.org/10.1016/j.clay.2012.04.020.

Zamparas M. and Zacharias I. (2014), Restoration of eutrophic freshwater by managing internal nutrient loads. A review, The Science of the Total Environment, https://doi.org/ 10.1016/j.scitotenv.2014.07.076.

Zeng L., Li X. and Liu J. (2004), Adsorptive removal of phosphate from aqueous solutions using iron oxide tailings, Water Research, 38, 1318-1326. https://doi.org/10.1016/ j.watres.2003.12.009. 